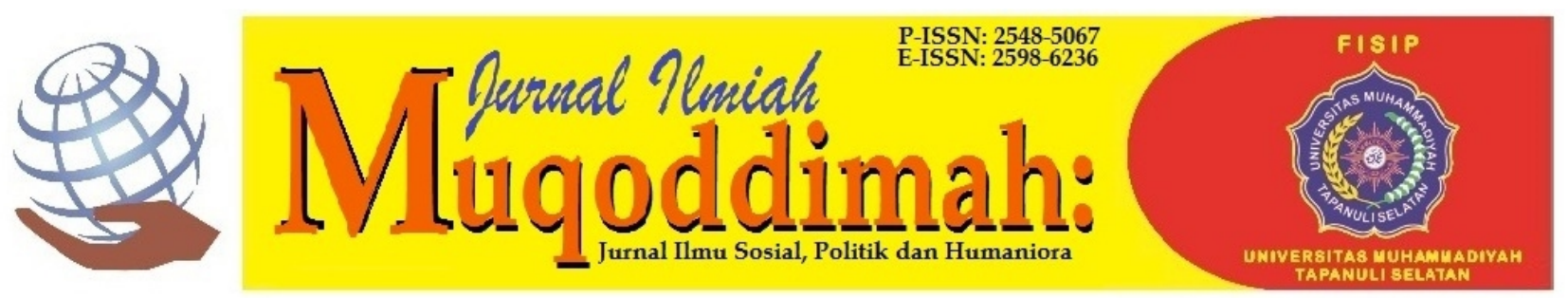

\title{
Implementasi Program Pembangunan Rumah Sederhana Sehat (PRSS) di Kota Tangerang
}

\author{
Dafyar Eliadi \\ Universitas Islam Syekh-Yusuf (UNIS), Tangerang \\ JI. Maulana Yusuf No. 10 Babakan. Kota Tangerang. Banten, Indonesia \\ dafyar711@unis.ac.id
}

\begin{abstract}
Abstrak
Program Pembangunan/Rehab Rumah Tidak Layak Huni (PR-RTLH) merupakan prioritas pembangunan Kota Tangerang sejak tahun 2014 hingga kini. Tujuan dari program ini adalah sebagai percepatan penanggulangan kemiskinan dengan upaya memenuhi hak dasar, mengurangi beban hidup, serta memperbaiki kualitas hidup masyarakat kurang mampu dengan membantu masyarakat memiliki rumah yang layak huni. Artikel ini dilaksanakan dengan menggunakan pendekatan implementasi kebijakan untuk memahami bagaimana implementasi PR-RTLH kota Tangerang terlaksana. Setelah melakukan penelitian dengan metode kualitatif dengan sumber data observasi dan studi pustaka, ditemukan bahwa implementasi program ini belum optimal dilakukan oleh pemerintah kota Tangerang. Pernyataan ini didapat setelah mempelajari proses bagaimana komunikasi pemerintah dilakukan dalam implementasi program ini. Meski jumlah rumah layak huni di kota Tangerang bertambah melebihi target yang telah ditetapkan, dalam implementasinya masih terdapat kekurangan dalam kontrol, komunikasi, serta sumber daya sehingga program berjalan kurang efektif.
\end{abstract}

Kata kunci: Implementasi, Pembangunan, PR-RTLH

\begin{abstract}
The Unworthy Housing Development / Rehabilitation Program (PR-RTLH) has been a priority for the development of Tangerang City since 2014 until now. The aim of this program is to accelerate poverty alleviation by fulfilling basic rights, reducing the burden of life, and improving the quality of life for underprivileged people by helping people have houses that are suitable for habitation. This article was conducted using a policy implementation approach to understand how the implementation of the PR-RTLH in Tangerang was carried out. After conducting research using qualitative methods with observational data sources and literature study, it was found that the implementation of this program was not optimal for the Tangerang city government. This statement is obtained after studying the process of how government communication is carried out in implementing this program. Although the number of livable houses in the city of Tangerang has increased beyond the predetermined target, in its implementation there are still deficiencies in control, communication, and resources so that the program runs less effectively.
\end{abstract}

Keywords: Implementation, Development, PR-RTLH

\section{PENDAHULUAN}

Chandler dan Plano menyatakan bahwa kehidupan manusia menjadi semakin kompleks sehingga apa yang akan dikerjakan oleh pemerintah atau administrasi publik juga akan semakin kompleks (Chandler, Ralph C., Plano, 2004). Nicholas Henry menambahkan salah satu ruang 
lingkup Administrasi Publik adalah implementasi yang menyangkut pendekatan terhadap kebijakan publik dan implementasinya, privatisasi, administrasi antar pemerintah serta etika birokrasi (Henry, 2015). Artikel ini akan secara mendalam membahas Implementasi Kebijakan Pembangunan Rumah Sederhana Sehat (PRSS) sebagai upaya menangani perumahan kumuh di Kota Tangerang Provinsi Banten dalam 10 tahun terakhir.

Pada tahun 2016, Pemerintah Kota Tangerang menetapkan 11 prioritas pembangunan Kota Tangerang. Salah satunya adalah pemenuhan kebutuhan dasar masyarakat melalui program Bedah Rumah dan Jamban Sehat. Kebijakan-kebijakan terkait bedah rumah ini juga diproyeksikan untuk menangani perumahan kumuh di Kota Tangerang. Prioritas dan sasaran pembangunan Kota Tangerang ini dibentuk dengan penyesuaian terhadap arah kebijakan pembangunan Provinsi Banten dan Pemerintah Pusat Republik Indonesia.

Program Bedah Rumah Kota Tangerang selaras dengan Program Tangerang Berbenah yang merupakan upaya untuk mewujudkan kota Tangerang yang layak huni. Sesuai dengan cita-cita ini, Kota Tangerang menargetkan pembangunan yang merata untuk meningkatkan kualitas hidup dan mengurangi permasalahan kemiskinan di 13 kecamatan di wilayah administratif kota tersebut (Pemerintah Kota Tangerang, 2017). Menurut Kementerian PUPR terdapat beberapa kriteria subjek penerima bantuan bedah rumah, diantaranya: Penerima merupakan warga negara Indonesia, masyarakat berpenghasilan rendah (MBR) dengan penghasilan di bawah UMP rata-rata nasional, sudah berkeluarga, memiliki tanah, belum memiliki rumah atau menghuni rumah tak layak huni, belum pernah menerima bantuan perumahan dari pemerintah, didahulukan yang memiliki rencana pembangunan/ peningkatan kualitas rumah, bersungguh-sungguh mengikuti program, dan dapat bekerja secara berkelompok (Erawan, 2016). Pemerintah Kota Tangerang juga mengadopsi kriteria-kriteria ini dimana pelaksanaan program bedah rumah melalui Badan Keswadayaan Masyarakat (BKM) dengan masyarakat terlibat langsung dalam mengawasi pelaksanaan pembangunan agar mencapai hasil yang maksimal (Pemerintah Kota Tangerang, 2017).

Dalam Surat Keputusan Walikota Tangerang pada tahun 2016 tentang Penetapan Kawasan Perumahan dan Permukiman yang Kumuh di Wilayah Kota Tangerang dijelaskan bahwa lokasi-lokasi yang merupakan Kawasan Perumahan dan Permukiman Kumuh memerlukan penanganan untuk meningkatkan kualitas kehidupan dan penghidupan masyarakat. Signifikansi tujuan ini dalam keberlangsungan kehidupan masyarakat membuat pemerintah Kota Tangerang mengalokasikan dana Anggaran Pendapatan dan Belanja Daerah (APBD) dalam jumlah besar untuk melaksanakan program ini secara berkelanjutan agar penanganan tuntas sebagaimana yang dicita-citakan. Sebagai bentuk komitmen, dalam jangka waktu lima tahun dari 2014-2019, Pemerintah Kota Tangerang telah menganggarkan dana sebesar Rp. $70.630 .982 .600,00$ atau sebesar lebih dari 70,6 miliar rupiah. Secara statistik, sejauh ini, berdasarkan dengan edaran Walikota, terdapat 16 kelurahan berstatus kumuh berat, 84 kelurahan berstatus kumuh sedang, dan 4 kelurahan berstatus kumuh ringan di Kota Tangerang. Secara kuantitas, dalam kurun waktu tersebut Pemerintah Kota Tangerang bersama-sama dengan masyarakat telah berhasil memperbaiki 6.678 rumah tak layak huni menjadi rumah layak huni sebagai progres dari program Tangerang Berbenah (Kabar Banten, 2020).

Dalam kaitannya dengan penataan kawasan kumuh, sejak tahun 2015 Pemerintah Kota Tangerang telah menyelaraskan tujuan tersebut dengan pembangunan hunian layak huni, pembangunan jalan setapak dan saluran drainase, hunian sehat, dan penyediaan air bersih. Masalah yang timbul dari program daerah ini adalah dana yang kurang memadai untuk tiap-tiap penerima manfaat serta kecilnya ruang untuk melakukan pembangunan di kawasan kumuh Kota Tangerang. Gambar di bawah ini menunjukkan hasil bedah rumah untuk rumah di kawasan kumuh Kota Tangerang. 


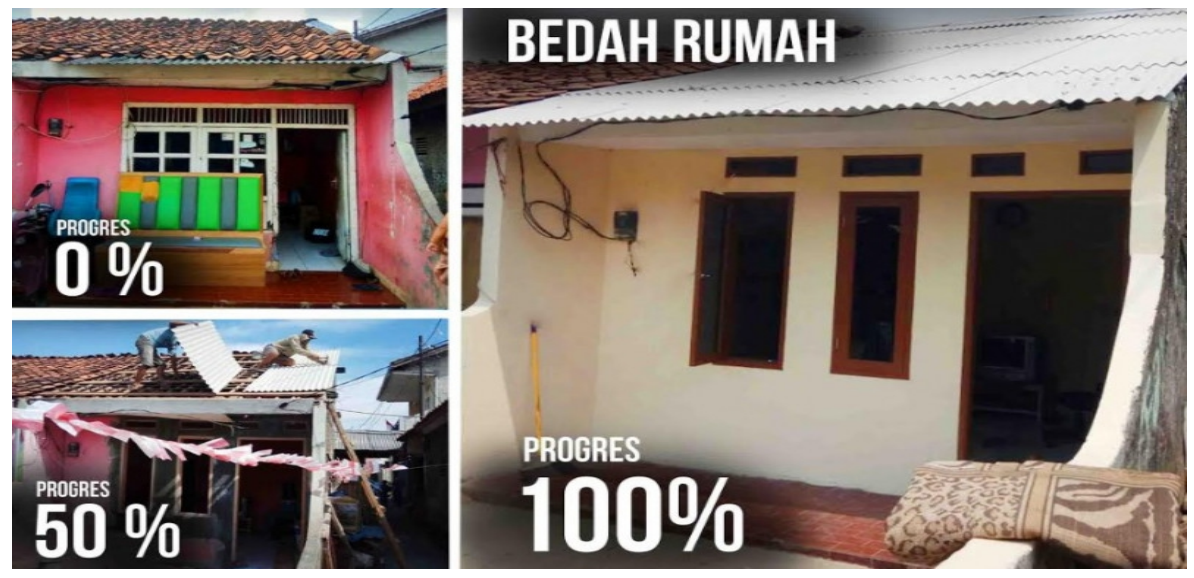

Gambar 1. Hasil Implementasi Program Bedah Rumah

Sebagaimana yang telah dijelaskan oleh Kementerian PUPR tentang Program Kota Tanpa Kumuh (KOTAKU), salah satu dari delapan indikator kota kumuh adalah Bangunan Gedung dengan penjabaran bahwa bangunan mengalami ketidakteraturan dalam hal dimensi, orientasi, dan bentuk; berada di lingkungan dengan kepadatan tinggi yang tidak sesuai dengan ketentuan dalam rencana tata ruang; serta, terdapat ketidaksesuaian dengan persyaratan teknis sistem struktur, pengamanan petir, penghawaan, pencahayaan, sanitasi, dan bahan bangunan. Sebagaimana terlihat pada gambar di atas, program bedah rumah di kawasan kumuh yang banyak terdapat di Kota Tangerang tidak menjadikan kawasan kumuh menjadi tidak lagi kumuh sehingga tujuan untuk mengatasi kawasan kumuh sepertinya belum tercapai. Meski begitu, terkait dengan tujuan untuk mengatasi sebagian masalah kemiskinan, program bedah rumah memberikan manfaat kepada masyarakat kota yang memenuhi kriteria dan membantu sebagian kebutuhan hidup dasar berupa hunian.

Sebagai sebuah isu terkini dan penting bagi kemaslahatan hidup masyarakat, terdapat beberapa artikel dan karya tulis yang juga berhubungan dengan Program Pembangunan Rumah Sederhana baik di Kota Tangerang maupun di kota lain di Indonesia. Beberapa di antaranya adalah artikel "Analisis dalam Implementasi Kebijakan Program Bedah Rumah di Kota Tangerang" (Ginanjar, 2019: 129-138). Artikel Ginanjar berfokus pada implementasi Kebijakan Program Bedah Rumah hanya di Kecamatan Cipondoh pada tahun 2016. Selain menggunakan pendekatan yang berbeda, artikel Ginanjar juga menginspirasi penulis untuk membahas penelitian secara lebih luas, tidak hanya di salah satu kecamatan namun secara menyeluruh di Kota Tangerang dengan lingkup waktu yang lebih baru. Selain itu, terdapat pula artikel berjudul "Bedah Rumah sebagai Bentuk Pengentasan Kemiskinan" (Hikmawati \& Gutomo, 2016: 131144) yang membahas tentang Program Bedah Rumah di Kab. Kulonprogo sebagai upaya pengentasan kemiskinan. Menariknya, penelitian Hikmawati dan Gutomo menunjukkan hasil positif yakni keberhasilan program yang melibatkan dukungan partisipasi dan sinergitas dari semua pihak terkait termasuk instansi-instansi, camat, pengusaha daerah, lembaga keuangan, serta gotong royong masyarakat. Penelitian ini menjadi landasan penelitian untuk melihat keberhasilan implementasi program PRSS dengan studi kasus di kota Tangerang. Berbeda dengan penelitian Hikmawati dan Gutomo yang berada dalam lingkup ilmu Kesejahteraan Sosial, penelitian ini berada dalam lingkup ilmu Administrasi Publik dengan pendekatan implementasi kebijakan publik. Berbeda dengan penelitian-penelitian sebelumnya, penelitian ini akan membahas bagaimana implementasi kebijakan yang diterapkan dalam Program Pembangunan Rumah Sederhana Sehat (PRSS) di Kota Tangerang dengan menganalisis bagaimana proses 
implementasi kebijakan tersebut dilakukan. Hal ini penting dilakukan sebagai bahan evaluasi dan perencanaan keberlanjutan program PRSS yang akan dijalankan kedepannya.

Program Pembangunan Rumah Sederhana Sehat (PRSS) di Kota Tangerang merupakan sebuah kebijakan yang diambil oleh Pemerintah Kota Tangerang dalam rangka menangani permasalahan rumuh kumuh di Kota Tangerang. Kebijakan sebagaimana dikemukakan oleh (Dye, 2005) adalah "... whatever a government chooses to do or even not to do", dengan kata lain segala sesuatu yang pemerintah lakukan atau tidak lakukan dapat disebut sebagai kebijakan. Selain itu, Dye menambahkan bahwa kebijakan publik merupakan pilihan yang dibuat oleh pemerintah untuk melakukan beberapa tindakan "public policy is, at its simplest, a choice made by government to undertake some course of action." Yang berarti tindakan berupa implementasi kebijakan merupakan tujuan dari dibuatnya kebijakan. Selanjutnya (Dye, 2005) menyatakan bahwa kebijakan publik dibuat dengan kesadaran penuh pemerintah; artinya, setiap konsekuensi yang bisa diperhitungkan dari kebijakan publik telah diantisipasi dengan sadar oleh pemerintah.

Jenkins (1978) juga mendefinisikan kebijakan publik sebagai Sekumpulan keputusan yang saling terkait yang diambil oleh aktor politik atau kelompok aktor mengenai pemilihan tujuan dan sarana untuk mencapainya. Berbeda dengan Dye, Jenkins melihat kebijakan publik bukan sebagai pilihan tetapi sebagai proses politik yang terdiri dari beberapa keputusan yang saling terhubung (program, undang-undang). Dalam penelitian ini, kebijakan menjadi satu atau sekumpulan keputusan yang diambil oleh pemerintah dalam rangka memecahkan suatu persoalan tertentu yang dihadapi oleh masyarakatnya. Seperti halnya kebijakan kemudian dilihat sebagai proses memilih strategi dan membuat pilihan, pembuatan kebijakan publik juga mencakup beberapa langkah seperti menciptakan agenda, perumusan kebijakan, adopsi kebijakan, hingga pada tingkat implementasi kebijakan (Raipa, 2002). Dikarenakan kebijakan dirumuskan untuk memecahkan suatu persoalan yang ada di masyarakat maka dalam merumuskan suatu kebijakan pemerintah bukan hanya perlu memperhatikan aspek teknis, melainkan juga harus memperhatikan aspek politis guna mengartikulasikan dan menyamakan tujuan dan sasaran di antara sesama aktor politik (Howlett \& Cashore, 2014). Kondisi yang digambarkan ini mengacu pada adanya suatu mekanisme pengambilan kebijakan dalam negara demokratis yang melibatkan dua lembaga, yaitu lembaga eksekutif dan lembaga legilatif.

Tahapan implementasi kebijakan dilakukan setelah sebuah kebijakan ditetapkan untuk melihat seberapa besar kebermanfaatan kebijakan tersebut bagi masyarakat. Van Meter \& Van Horn (1975) menambahkan bahwa implementasi kebijakan merupakan tindakan-tindakan yang dilakukan baik oleh individu, pejabat, pemerintah, maupun swasta yang diarahkan pada tercapainya tujuan-tujuan yang telah dibuat dalam putusan kebijakan. Implementasi kebijakan termasuk didalamnya mengubah suatu keputusan menjadi bentuk operasional, serta upaya berkelanjutan untuk mencapai perubahan yang diamanatkan oleh keputusan kebijakan (Sirajuddin, 2016; van Meter \& van Horn, 1975).

Dalam artikelnya Van Meter \& Van Horn (1975) menjelaskan bahwa implementasi kebijakan (policy implementation) berbeda dengan dampak kebijakan (policy impact). Ketika dampak kebijakan berorientasi pada hasil yang terukur dan dampak yang nyata, implementasi kebijakan berbicara mengenai proses dan kinerja program, berbicara mengenai sesuatu yang berkelanjutan. Hasil dari implementasi kebijakan yang efektif tidak selalu berbicara mengenai hasil perubahan atau dampak yang signifikan, bisa saja sesederhana perkembangan menjadi kondisi yang diperlukan. Akan tetapi yang tidak bisa dilepaskan dari adanya implemetasi kebijakan adalah bahwa implementasi harus berorientasi pada upaya mewujudkan suatu tatanan pemerintahan yang baik (good governance) (Solihah et al., 2017)

Untuk menganalisis implementasi kebijakan Program Pembangunan Rumah Sederhana Sehat (PPRS) di Kota Tangerang penelitian ini menggunakan model top down. Dalam pandangan Pressman \& Wildavsky (1973) bahwa model top down dapat dianalisa dengan 
memperhatikan kontrol dan komunikasi, serta sumberdaya yang digunakan untuk melakukan pekerjaan. Adapun dalam pandangan Van Meter \& Van Horn (1975) keberhasilan implementasi kebijakan perlu memperhatikan dimensi: standar kebijakan dan tujuan, sumber daya dan insentif yang dimiliki, kualitas hubungan di dalam organisasi, karakteristik pelaksana implementasi, lingkungan sosial, ekonomi dan politik, serta disposisi atau jawaban dari pelaksana. Dari kedua model tersebut penelitian ini menggunakan model yang dikemukakan oleh (Pressman \& Wildavsky, 1973).

\section{METODE}

Desain penelitian ini menggunakan metode kualitatif. Metode penelitian dipilih dan dianggap tepat karena dianggap relevan dan cocok dengan masalah penelitian yang diajukan melalui interpretasi proses dan makna. Dengan metode kualitatif maka sumber data penelitian ini dikumpulkan dari data primer yang berupa hasil observasi, serta data sekunder di lapangan.

Data sekunder yang dijaring adalah melalui studi dokumentasi, yaitu data yang diperoleh melalui dokumentasi yang relevan dengan penelitian ini.

Pengujian keabsahan data dalam penelitian ini didasarkan pada kriteria tertentu, yaitu derajat kepercayaan dan kebenaran data (credibility) yang diperoleh dari informan-informan yang terlibat dalam pembentukan komunikasi politik maupun yang mengetahui tentang implementasi kebijakan Program Pembangunan Rumah Sederhana Sehat (PRSS) di Kota Tangerang, kebenaran (correctness) suatu deskripsi, simpulan, dan penjelasan (explanation) yang dapat diketahui dari kesesuaian dengan peraturan perundangan serta naskah/dokumen penting lainnya.

\section{HASIL DAN PEMBAHASAN}

\section{Dasar Kebijakan Program Bedah Rumah Indonesia}

Hingga 2020, telah terjadi berbagai perkembangan terkait program bedah rumah Indonesia. Program-program bedah rumah tersebut beragam jenis dan nama tergantung pada institusi penyelenggara, sebagian besar dari pemerintahan pusat dan daerah, namun banyak lainnya berasal dari program Corporate Social Responsibility (CSR) yang diselenggarakan oleh perusahaan-perusahaan yang menetap di berbagai penjuru Indonesia. Penelitian ini berfokus pada program-program bedah rumah yang diselenggarakan oleh Pemerintahan Indonesia baik secara nasional maupun dalam pemerintahan daerah untuk dapat memahami implementasi Program Pembangunan Rumah Sederhana Sehat (PRSS) di kota Tangerang.

Secara nasional, skema program bedah rumah di Indonesia dijelaskan dalam cetak "Program Bantuan Pemerintah untuk Individu, Keluarga, dan Kelompok Tidak Mampu Menuju Bantuan Sosial Terintegrasi" yang diterbitkan oleh Tim Nasional Percepatan Penanggulangan Kemiskinan Indonesia. Pada program di bidang perumahan, terdapat dua kementerian yang menyelenggarakan program bantuan pemerintah untuk masyarakat kurang mampu yakni Kementerian Sosial dan Kementerian PUPR. Program Kemensos bernama Rehabilitasi Sosial untuk Rumah Tidak Layak Huni (RS-RTLH), sementara program KemenPUPR adalah Bantuan Stimulan Perumahan Swadaya (BSPS) (Palaon et al., 2018). Sementara itu, sejalan dengan kebijakan pemerintah nasional, pemerintahan daerah juga melakukan program bedah rumah dengan penamaan program masing-masing dengan alokasi dana berasal dari Anggaran Pendapatan dan Belanja Daerah serta aliran lain yang telah ditetapkan oleh daerah masingmasing. sebagai berikut:

Secara konstitusi, program RS-RTLH berasal dari dasar hukum dan perundangan

1) Undang-undang nomor 11 tahun 2009 tentang Kesejahteraan Sosial

2) Undang-undang nomor 13 tahun 2011 tentang Penanganan Fakir Miskin 
3) Peraturan Pemerintah Nomor 39 tahun 2012 tentang Penyelenggaraan Kesejahteraan Sosial

4) Peraturan Pemerintah Nomor 42 tahun 1981 tentang Pelayanan Kesejahteraan Sosial bagi Fakir Miskin

5) Keputusan Menteri Sosial Nomor 84/HUK/1997 tentang Pelaksanaan Pemberian Bantuan Sosial bagi Keluarga Fakir Miskin

6) Keputusan Menteri Sosial Nomor 19/HUK/1998 tentang Pelayanan Kesejahteraan Sosial bagi Fakir Miskin yang diselenggarakan masyarakat

7) Petunjuk Pelaksanaan Rehabilitasi Sosial Rumah Tidak Layak Huni dan Sarana Lingkungan tahun 2017.

Sementara itu, program BSPS KemenPUPR berasal dari peraturan dan perundangan sebagai berikut:

1) UU Nomor 1/ 2011 tentang Perumahan dan Kawasan Permukiman

2) Peraturan Pemerintah Nomor 88 Tahun 2014 tentang Pembinaan Penyelenggaraan Perumahan dan Kawasan Pemukiman

3) Peraturan Menteri Keuangan Nomor 168/PMK.05/2015 tentang Mekanisme Pelaksanaan Anggaran Belanja Bantuan Pemerintah pada Kementerian/Lembaga Negara.

4) Peraturan Menteri Pekerjaan Umum dan Perumahan Rakyat Nomor 13/PRT/M/2016 tentang Bantuan Stimulan Perumahan Swadaya.

Terkait dengan kebijakan pemerintahan daerah terkait dengan bedah rumah, pada tahun 2016 lalu, Sekretaris Direktorat Jenderal Penyediaan Perumahan Kementerian PUPR menyampaikan bahwa pemerintah daerah perlu untuk menciptakan program perumahan yang nyata di daerah masing-masing. Hal ini dikarenakan dana yang dimiliki oleh KemenPUPR untuk menjalankan program BSPS terbatas dan tidak mampu untuk memenuhi bantuan perumahan secara menyeluruh bagi masyarakat yang membutuhkan. Pemerintah Daerah diminta untuk memiliki masterplan pembangunan perumahan sebagaimana yang juga dimiliki oleh pemerintah pusat agar penanganan terhadap masalah ini menjadi lebih optimal (Ristyan, 2016).

\section{Kebijakan PRSS Pemerintahan Kota Tangerang}

Kebijakan yang diambil oleh Pemerintah Kota Tangerang untuk melakukan program bedah rumah didasari oleh keinginan untuk membantu warga yang kurang mampu agar mendapatkan rumah tinggal yang layak huni. Selain itu, kebijakan ini juga dilaksanakan dengan tujuan percepatan penanggulangan kemiskinan dengan upaya memenuhi hak dasar, mengurangi beban hidup, serta memperbaiki kualitas hidup masyarakat kurang mampu (Palaon et al., 2018). Kebijakan ini diharapkan mampu memberikan manfaat bagi masyarakat, terutama untuk meningkatkan kesejahteraan mereka. Dengan memiliki rumah tinggal yang layak huni diharapkan tingkat kesehatan masyarakat akan meningkat, oleh sebab rumah layak huni yang dicanangkan oleh Pemerintah Kota Tangerang adalah rumah dengan sistem sirkulasi udara dan tata kelola air yang baik bagi kesehatan. Pemerintah Kota Tangerang juga meyakini bahwa semakin banyak masyarakat yang memiliki rumah layak huni juga akan mendorong Kota Tangerang menjadi kota yang layak huni (Tangerang Online, 2019). Program ini digiatkan sebab ditemukan banyak masalah terkait perumahan seperti banyaknya rumah yang tidak layak huni dengan sistem sirkulasi udara yang tidak baik, atap yang bocor, lantai yang hanya dibalut lapisan semen atau hanya beralaskan tanah, dinding yang tidak di plester, sistem drainase yang buruk, dan rumah yang kumuh (Tangerang Online, 2019; Tohir, 2019). Dengan banyaknya kondisi rumah tidak layak huni yang ditempati oleh warga Kota Tangerang maka Pemerintah Kota Tangerang merasa memiliki suatu kewajiban untuk memenuhi kebutuhan dasar masyarakat (Pemerintah Kota Tangerang, 2018).

Secara konstitusi, kebijakan Kota Tangerang terkait dengan perumahan yang terbaru tertuang dalam Peraturan Daerah Nomor 5 tahun 2017 tentang Penyerahan Prasarana, Sarana 
dan Utilitas Perumahan. Dalam Perda ini dijelaskan bahwa Kota Tangerang menyatakan setiap orang berhak hidup sejahtera lahir dan batin, bertempat tinggal, dan mendapatkan lingkungan hidup yang baik dan sehat sebagai kebutuhan dasar manusia, yang berperan strategis dalam pembentukan watak serta kepribadian bangsa sebagai salah satu upaya membangun manusia Indonesia seutuhnya. Selanjutnya, peraturan terkait PRSS secara lebih detail dan terbaru tertuang dalam Peraturan Walikota Tangerang Nomor 5 Tahun 2019 tentang Bantuan Sosial Kegiatan Pembangunan Sarana dan Prasarana Rumah Sederhana Sehat tahun anggaran 2019. Dalam Perwal ini, disebutkan bahwa Pembangunan/Rehab Rumah Tidak Layak Huni (PR-RTLH) merupakan proses meningkatkan kualitas tempat tinggal melalui perbaikan kondisi rumah, baik secara menyeluruh maupun sebagian menjadi agar tercipta kondisi rumah yang layak sebagai tempat tinggal. Dalam Pasal 2 Perwal tersebut dijelaskan pula bahwa pengadaan PR-RTLH bertujuan untuk mendukung program Tangerang Berbenah dan Pemerintah melalui: peningkatan kualitas tempat tinggal MBR, mengurangi kawasan kumuh di daerah, serta peningkatan peran serta dan swadaya masyarakat setempat dengan semangat kebersamaan, gotong royong, dan nilai dalam penggalangan kepedulian sosial.

Kebijakan bedah rumah untuk mewujudkan rumah layak huni telah di implementasikan oleh Pemerintah Kota Tangerang sejak tahun 2014. Selama kurun waktu tahun 2014-2018 sebanyak 5.925 unit rumah telah berhasil dibangun atau dibedah dengan target awal hanya sebanyak 5.000 rumah. Hal ini menunjukkan bahwa secara kuantitas, implementasi kebijakan berjalan sangat baik dimana jumlah RTLH yang dijadikan layak huni melebihi angka yang telah ditargetkan sebelumnya. Di awal kebijakan ini dijalankan pada tahun 2014, Pemerintah Kota Tangerang berhasil membedah 53 unit RTLH. Pada tahun 2015, terjadi peningkatan yang signifikan dari jumlah sebelumnya menjadi 1.107 unit RTLH. Pada tahun 2016, jumlah PR-RTLH kembali meningkat menjadi bedah 1.451 unit RTLH, tahun 2017 jumlahnya meningkat dua kali lipat, yaitu sebanyak 2.314 unit RTLH, dan di tahun 2018 sebanyak 1.323 unit RTLH (Fauzi, 2019; Pemerintah Kota Tangerang, 2018).

Keberhasilan implementasi kebijakan yang mensyaratkan suatu keberlanjutan untuk mencapai tujuan yang telah diamanatkan sebagaimana yang dinyatakan oleh Van Metter dan Van Horn ditunjukkan dengan program PR-RTLH yang terus dijalankan dan membantu kebutuhan tempat tinggal masyarakat berpendapatan rendah. Sebagaimana dikemukakan oleh Walikota Tangerang, Arief Wismansyah, bahwa dalam implementasi kebijakan PRSS di tahun 2019 terdapat 500 Rumah Tidak Layak Huni (RTLH) yang direncanakan untuk dibedah (renovasi) (Tangerang Online, 2019). Dari target 500 RTLH yang ditetapkan oleh Pemerintah Kota Tangerang akan di renovasi, sebagaimana data yang kemudian didapatkan oleh penelitian ini bahwa baru terdapat 250 RTLH yang berhasil di renovasi oleh Pemerintah Kota Tangerang (Tohir, 2019). Meskipun jumlah capaian program bedah rumah di tahun 2019 tidak sesuai dengan target yang telah ditetapkan, namun bila merujuk pada kebijakan yang telah dijalankan sejak tahun 2014 dengan angka rumah yang berhasil di bedah oleh Pemerintah Kota Tangerang maka telah menunjukkan adanya keseriusan Pemerintah Kota Tangerang untuk membantu mengatasi permasalahan RTLH dan dalam rangka mewujudkan Kota Tangerang sebagai kota yang ramah dan layak huni melalui program besar Tangerang Berbenah.

Untuk menganalisis implementasi kebijakan PR-RTLH kota Tangerang, ada tiga variabel yang digunakan oleh peneliti, yaitu logika kebijakan, lingkungan tempat kebijakan dioperasikan, dan kemampuan implementor kebijakan.

\section{Kontrol Pemerintah}

Kontrol oleh pemerintah dalam suatu implementasi kebijakan memainkan peran penting agar suatu kebijakan yang telah ditetapkan dapat mencapai sasarannya. Kebijakan Program Pembangunan Rumah Sederhana Sehat (PRSS) yang dijalankan oleh Pemerintah Kota Tangerang dijalankan dengan mekanisme kontrol yang cukup ketat, cara ini dilakukan agar 
implementasi kebijakan dapat mencapai tujuan atau sasaran yang telah ditetapkan, disamping juga untuk menghindari adanya penyalahgunaan kewenangan oleh aparatur pelaksana kebijakan. Berdasarkan pada data yang diperoleh bahwa setidaknya di tahun 2019 Pemerintah Kota Tangerang telah menganggarkan dana APBD sebanyak Rp. 20 Miliar untuk program bedah rumah atau Program Pembangunan Rumah Sederhana Sehat (PRSS) (Joniansyah, 2019).

Berdasarkan data yang diperoleh bahwa dalam implementasinya kontrol yang dilakukan oleh Pemerintah Kota Tangerang dalam implementasi kebijakan PRSS dilakukan baik secara top down maupun bottom up. Kontrol yang bersifat top down dilakukan dengan mekanisme pengawasan langsung dari Tim Tangerang Bebenah yang Koordinatornya dipegang oleh Dinas Perumahan dan Permukiman (Perkim), dimana di dalam tim tersebut juga terdapat Dinas PUPR, Dinas Sosial, Bappeda, Dinas Pemberdayaan Perempuan dan Perlindungan Anak Pengendalian Penduduk dan Keluarga Berencana (DP3AP2KB), inspektorat, Tim Pengawal dan Pengamanan Pemerintah dan Pembangunan Daerah (TP4D) Kejari Tangerang. Secara khusus TP4D Kejari Tangerang melakukan pengawasan penggunaan anggaran agar tidak terjadi korupsi atau penyimpangan penggunaan anggaran (Wibisana, 2018)

Sedangkan kontrol yang bersifat bottom up dilakukan secara berjenjang, mulai dari bawah di tingkat kelurahan, kecamatan dan sampai tingkat pemerintah kota. Untuk keterlibatan masyarakat dalam kontrol implementasi kebijakan ini juga diantaranya dilakukan oleh Badan Keswadayaan Masyarakat (BKM) dan Forum Kota Tanpa Kumuh (FKTK). Baik BKM dan FKTK disertakan untuk melakukan pengawasan mulai dari penentuan serta penetapan penerima bantuan program bedah rumah sehingga dapat tepat sasaran, spesifikasi bangunan sampai dengan pengawasan penggunaan angggaran oleh pelaksana kerja.

Pengawasan berlapis baik yang dilakukan secara top down atau bottom up merupakan yang penting, dengan pengawasan berlapis ini maka akan dapat dihindari adanya potensi kesalahan dalam penentuan penerima bantuan atau adanya kerugian anggaran akibat dari adanya penyalahgunaan wewenang oleh pelaksana program di lapangan. Kontrol sesungguhnya merupakan syarat mutlak bagi optimalisasi implementasi kebijakan, dengan adanya kontrol atau pengawasan maka standar-standar pelaksanaan kebijakan harus dipenuhi sehingga mekanisme pertanggungjawaban juga menjadi jelas. Pengawasan berlapis yang dilakukan oleh Pemkot Tangerang dalam implementasi kebijakan PRSS juga menjadi suatu upaya untuk memastikan adanya akuntabilitas dan kepastian hukum.

\section{Komunikasi Pemerintah}

Komunikasi pemerintah memainkan peran penting lainnya dalam implementasi suatu kebijakan, komunikasi ini dilakukan oleh pemerintah kepada masyarakat atau antar lembaga pemerintahan. Dalam komunikasi pemerintahan yang berkenaan dengan posisi pemerintah selaku pembuat kebijakan dengan masyarakat sebagai pihak yang dikenakan kebijakan, maka komunikasi pemerintahan digunakan untuk mengenalkan atau mensosialisasikan suatu kebijakan kepada masyarakat, seperti apa maksud dan tujuan dari kebijakan PRSS. Pentingnya komunikas pemerintah kepada masyarakat juga dimaksudkan agar sistem berjalan dengan efektif, pemerintah harus berkomunikasi dengan rakyatnya sebab rakyat memiliki hak untuk mengetahui apa yang sedang dilakukan oleh perangkat pemerintahan, masyarakat perlu untuk mengetahui mengapa suatu kebijakan dibuat.

Informasi yang diberikan oleh pemerintah harus bersifat kredibel dan tepat waktu. Oleh sebab itu, untuk menjangkau masyarakat secara menyeluruh, pemerintah harus bergantung pada media yang berperan dalam memfilter dan menyajikan informasi kepada publik secara elektronik maupun cetak. Komunikasi pemerintah menuntut setiap perubahan yang mempengaruhi tatanan masyarakat dikomunikasikan secara efektif kepada setiap yang 
berkepentingan, baik kepada kalangan pemerintahan, pihak-pihak swasta, maupun masyarakat luas secara berkelanjutan.

Dalam hal komunikasi yang dilakukan oleh pemerintah kepada masyarakat Pemerintah Kota Tangerang telah berupaya mensosialisasikan kepada masyarakat, baik melalui meda cetak atau elektronik, bahwa Pemkot Tangerang mempunyai kebijakan yang disebut Tangerang LIVE. LIVE merupakan kepandangan dari Liveable, Invenstable, Visitable dan E-City. Tangerang LIVE artinya Kota yang Liveable (Layak huni), Investable (Primadona bagi Investor), Visitable (Wisata) dan E-City (Berbasis teknologi Elektronik). Jadi 4 (empat) hal tersebut menjadi Program Walikota Tangerang untuk mensejahterakan masyarakatnya. Terkait dengan PRSS maka program ini merupakan bagian dari upaya mewujudkan kota yang liveable (layak huni).

Pemkot Tangerang, sebagaimana disampaikan oleh Dinas Perkim selalu mengkomunikasikan kepada masyarakat kebijakan PPRS melalui sosialisasi pentingnya lingkungan yang sehat di kecamatan-kecamatan, organisasi masyarakat dan perguruan tinggi, selanjutnya mendata rumah -rumah yang perlu dibangun karena tidak layak huni. Dengan sosialisasi ini masyarakat dapat semakin memahami apa yang menjadi maksud dan tujuan dari kebijakan PPRS, diantaranya untuk mewujudkan rumah tinggal yang layak huni.

Terkait dengan implementasi kebijakan bedah rumah yang diselenggarakan oleh pemerintah Kota Tangerang, telah terdapat komunikasi yang dilakukan pemerintah untuk menunjukkan kinerja dan progres program tersebut. Hanya saja, hasil observasi menunjukkan bahwa komunikasi pemerintah yang dilakukan belum dilakukan secara komprehensif, tidak terjadwal dan belum dilakukan secara berkala. Sebagai contoh, pemberitaan mengenai progres bedah rumah terakhir yang diterbitkan pemerintah Kota Tangerang di Situs Resmi Pemerintah Kota Tangerang adalah pada tanggal 13 November 2018 dengan judul, "Hingga Akhir Tahun, Bedah Rumah Capai 6.248 Unit". Selain itu, komunikasi yang dilakukan melalui berita resmi ini hanya dilakukan dua kali pada tahun 2018, dan tidak dilakukan sama sekali pada tahun 2019 dan 2020 di Situs Resmi tersebut (www.tangerangkota.go.id).

Sebenarnya situs resmi yang diterbitkan oleh Pemerintah Kota Tangerang dapat menjadi wadah bagi masyarakat untuk mengetahui perkembangan terbaru dari implementasi kebijakan PR-RTLH yang sedang berjalan. Hal ini menunjukkan bahwa dalam indikator komunikasi yang dilakukan oleh pemerintah Kota Tangerang masih belum optimal dilakukan sehingga implementasi kebijakan tidak secara efektif diterima dan dipahami oleh masyarakat.

\section{Sumber Daya}

Unsur sumber daya merupakan hal yang penting bagi efektivitas pelaksanaan kebijakan. Sebaik dan sebanyak apapun kebijakan yang ditetapkan, namun tanpa sumber daya yang memadai, akan sangat sulit suatu kebijakan dapat diimplementasikan dengan baik (Yalia, 2014). Aspek sumber daya dalam implementasi kebijakan meliputi pemanfaatan sumber daya manusia, biaya dan waktu, dimana ketiganya menjadi penunjang dalam menentukan keberhasilan implementasi kebijakan. Berkenaan dengan sumber daya manusia yang dimiliki oleh Pemerintah Kota Tangerang dalam pelaksanaan kebijakan PPRS, maka beberapa Aparatur Sipil Negara (ASN) dari Dinas Perkim, Dinas PUPR, Dinas Sosial, Bappeda, serta Dinas Pemberdayaan Perempuan dan Perlindungan Anak Pengendalian Penduduk dan Keluarga Berencana (DP3AP2KB) yang dilibatkan sebagai pelaksana. Setiap personel ASN pada dinas tertentu bekerja sesuai dengan tugas pokok dan fungsinya, hal ini juga merupakan bagian daripada sinergitas antar instansi dalam Pemkot Tangerang.

Sumber daya lainya, yaitu anggaran atau keuangan juga telah dilihat oleh Pemerintah Kota Tangerang sebagai faktor pendukung keberhasilan kebijakan PPRS. Kebijakan PPRS ini dibiayai oleh APBD Kota Tangerang dari tahun 2015 - 2019 dengan dana sebesar Rp. 70.630.982.600,00 (Tujuh puluh Milyar Enam Ratus Tiga Puluh Juta Sembilan ratus Delapan puluh dua ribu Enam ratus rupiah). Dengan dukungan pembiayaan yang mencukupi maka 
program bedah rumah dapat bermanfaat bagi kehidupan masyarakat, namun dalam merumuskan besaran anggaran yang diperlukan juga sebelumnya dilakukan kajian oleh beberapa dinas dan badan yang terkait, seperti Dinas Perkim dan Bappeda.

\section{SIMPULAN DAN SARAN}

Implementasi suatu kebijakan tidak dapat dipandang hanya melalui dampak dari pelaksanaan kebijakan tersebut. Lebih jauh lagi, implementasi berbicara mengenai suatu proses yang berkelanjutan dan bagaimana suatu kebijakan dioperasionalkan sehingga tidak lagi hanya berbentuk keputusan-keputusan yang tidak terlaksana. Terkait dengan implementasi program PRSS di Kota Tangerang secara statistik terlihat dampak yang pasti dari implementasi kebijakan. Artinya, perjalanan kebijakan dalam lima tahun sejak 2014 hingga 2018 yang berhasil memberikan bantuan bedah rumah kepada 6.248 RTLH secara kasat mata terlihat melebihi target kebijakan yang hanya bertekad untuk membantu 5.000 RTLH. Namun, implementasi kebijakan dipahami sebagai sebuah proses dimana salah satu variabelnya adalah komunikasi pemerintah yang dalam hal ini pemerintah Kota Tangerang menunjukkan lemahnya komunikasi yang terbentuk terkait dengan pelaporan perkembangan kebijakan kepada pihak-pihak terkait memberikan kesimpulan bahwa implementasi kebijakan ini belum secara optimal dilaksanakan. Sebagai sebuah kebijakan yang berkelanjutan, optimalisasi komunikasi pemerintah dapat dilakukan agar tercapai tujuan kebijakan sebagaimana yang telah disebutkan sebelumnya. Meskipun masih ada kelemahan dari sisi komunikasi, namun aspek pengawasan (kontrol) telah diakukan secara top down dan bottom up, begitupun dengan aspek sumber daya, dimana dukungan sumber daya dari berbagai instansi di dalam Pemerintah Kota Tangerang dilibatkan secara penuh

\section{DAFTAR PUSTAKA}

Chandler, Ralph C., Plano, J. C. (2004). The Public Administration Dictionary. In John Wiley \& Sons.

Dye, T. R. (2005). Understanding Public Policy. In Understanding Public Policy.

Erawan, A. (2016, February 3). Apa Syarat Dapat Bantuan Bedah Rumah dari Pemerintah? | Pasar Properti | Rumah.com. Rumah.Com. https://www.rumah.com/beritaproperti/2016/2/116598/apa-syarat-dapat-bantuan-bedah-rumah-dari-pemerintah

Fauzi, A. I. (2019, December 30). 2020, Pemkot Tangerang Targetkan Bedah 750 Rumah. TangerangNews.Com. https://tangerangnews.com/kota-tangerang/read/29655/2020Pemkot-Tangerang-Targetkan-Bedah-750-Rumah

Ginanjar, A. (2019). Analisis dalam Implementasi Kebijakan Program Bedah Rumah di Kota Tangerang. Journal of Government and Civil Society Vol. 3, No. 2, 129-138. doi: 10.31000/jgcs.v3i2.1816.

Henry, N. (2015). Public Administration and Public Affairs. In Public Administration and Public Affairs. https://doi.org/10.4324/9781315663067

Hikmawati, E. \& Gutomo, T. (2016). Bedah Rumah Sebagai Bentuk Pengentasan Kemiskinan. Jurnal PKS Vol. 15 No. 2, 131-144.

Howlett, M., \& Cashore, B. (2014). Conceptualizing Public Policy. In Comparative Policy Studies. https://doi.org/10.1057/9781137314154_2

Jenkins, W. (1978). Policy Analysis: A Political and Organizational Perspective. Martin Robertson.

Joniansyah. (2019, October 17). Kabupaten Tangerang Gelar Bedah Rumah dan 20 Kawasan Kumuh - Metro Tempo.co. Tempo.Co. https://metro.tempo.co/read/1260809/kabupatentangerang-gelar-bedah-rumah-dan-20-kawasan-kumuh/full\&view=ok 
Kabar Banten. (2020, January 2). 2020, Pemkot Tangerang Targetkan Bedah 750 Rumah. Kabar-Banten.Com. https://www.kabar-banten.com/2020-pemkot-tangerang-targetkanbedah-750-rumah/

Mazmanian, D. A. ;, \& Sabatier, P. A. (1989). Implementation and Public Policy. University Press of America.

Palaon, H., Dewi, L. A., \& Purnagunawan, M. (2018). Program Bantuan Pemerintah Untuk Individu, Keluarga, dan Kelompok Tidak Mampu Menuju Bantuan Sosial Terintegrasi.

Pemerintah Kota Tangerang. (2017). Program Bedah Rumah Wujudkan Kota Layak Huni Pemerintah Kota Tangerang. Tangerangkota.Go.ld. https://tangerangkota.go.id/programbedah-rumah-wujudkan-kota-layak-huni

Pemerintah Kota Tangerang. (2018, December). Bangun 5.925 Rumah Layak Huni dan 4.003 Jamban Keluarga Sehat - Pemerintah Kota Tangerang. Tangerangkota.Go.Id. https://tangerangkota.go.id/bangun-5925-rumah-layak-huni-dan-4003-jamban-keluargasehat

Pressman, J. L., \& Wildavsky, A. B. (1973). Implementation : how great expectations in Washington are dashed in Oakland. The Oakland Project Series.

Raipa, A. (2002). Public Policy and Public Administration: Development, Structure and Reciprocity. Viesoji Politika Ir Administravimas.

Ristyan. (2016, January 25). Pemda Diminta Alokasikan Dana APBD Untuk Program Bedah Rumah. Kementerian Pekerjaan Umum Dan Perumahan Rakyat. https://www.pu.go.id/berita/view/11826/pemda-diminta-alokasikan-dana-apbd-untukprogram-bedah-rumah

Sirajuddin, I. A. (2016). Implementasi Kebijakan Pemerintah Daerah Dalam Pelayanan Publik Dasar Bidang Sosial Di Kota Makassar. Jurnal IImiah IImu Administrasi Publik. https://doi.org/10.26858/JIAP.V4I1.1817.

Solihah, R., Djuyandi, Y., Witianti, S., \& Herdiansah, A. G. (2017). The importance of good governance implementation in the legislative institutions. Advanced Science Letters, 23(5). https://doi.org/10.1166/asl.2017.8917

Tangerang Online. (2019, December 28). Program Bedah Rumah, Salah Satu Bentuk Perhatian Pemerintah Kota Tangerang. Tangerangonline.Id.

https://tangerangonline.id/2019/12/28/program-bedah-rumah-salah-satu-bentuk-perhatianpemerintah-kota-tangerang/

Tohir, J. R. (2019). Tahun 2019, Pemkot Tangerang Selatan Klaim Sudah Bedah 250 Rumah Warga yang Reot - Tribun Jakarta. TribunJakarta.Com. https://jakarta.tribunnews.com/2019/12/26/tahun-2019-pemkot-tangerang-selatan-klaimsudah-bedah-250-rumah-warga-yang-reot

van Meter, D. S., \& van Horn, C. E. (1975). The Policy Implementation Process: A Conceptual Framework. Administration \& Society. https://doi.org/10.1177/009539977500600404

Wibisana, H. (2018, July 20). 1.000 Rumah di Kota Tangerang Dibedah Tahun Ini - bantenhits. Bantenhits.Com. https://bantenhits.com/2018/07/20/1-000-rumah-di-kota-tangerangdibedah-tahun-ini/

Yalia, M. (2014). Implementasi Kebijakan Pengembangan dan Pemberdayaan Lembaga Sosial Media Tradisional di Jawa Barat. Patanjala, Jurnal Penelitian Sejarah Dan Budaya, 6(1), 149-160. 